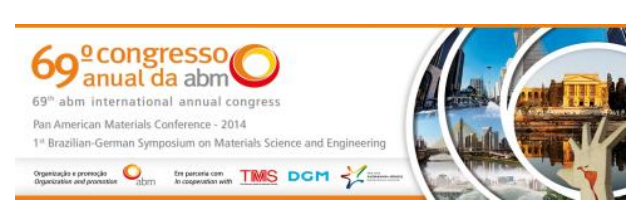

Theme: Phase diagrams and phase transformations

\title{
METALLIC INTERCONNECTS FOR APPLICATION IN HIGH TEMPERATURE SOLID OXIDE FUEL CELLS (SOFCS): THERMODYNAMIC STUDY OF THE OXIDATION OF FERRITIC STAINLESS STEELS*
}

Aline Lima da Silva ${ }^{1}$ Nestor Cezar Heck²

\begin{abstract}
The reduction in SOFC operating temperature due to recent development in materials and fabrication techniques enables the use of ferritic stainless steels as interconnects for SOFCs. Ferritic stainless steels offer many advantages over traditional ceramic interconnects, such as higher thermal and electronic conductivity, as well as relative ease of fabrication. However, the formation of chromium oxide on ferritic stainless steel results in an increase in ohmic resistance and can lead to the loss of cathode catalytic activity (due to $\mathrm{Cr}$ volatilization, with cathode poisoning). The oxide growth depends on several factors, such as steel composition, temperature, oxygen partial pressure. In this way, knowing the phase stability, the oxidation behavior of the material and the oxidation kinetics is of great interest. In this context, a thermodynamic study of the oxidation of ferritic stainless steel 430 under oxidizing atmosphere (cathode), at the temperature of $750^{\circ} \mathrm{C}$, is carried out. As one can see, the thermodynamic system can be very complex, involving several phases (chromium oxide, (Fe, $\mathrm{Cr}, \mathrm{Mn})_{3} \mathrm{O}_{4}$ Spinel, iron-chromium oxides, etc.). The effect of oxygen partial pressure and alloying elements on phase distribution is evaluated. Thermodynamic modeling is compared with experimental results from literature.
\end{abstract}

Keywords: Oxidation; Ferritic stainless steels; Thermodynamics; Phase diagram.

1 Metallurgical Engineer, Dr., Postdoctoral Researcher, Núcleo de Termodinâmica Computacional para a Metalurgia (NTCm), Depto. de Metalurgia, PPGE3M, UFRGS, Porto Alegre, RS, Brasil; adasilva26@gmail.com.

2 Metallurgical Engineer, Dr., Professor, Núcleo de Termodinâmica Computacional para a Metalurgia (NTCm), Depto. de Metalurgia, PPGE3M, UFRGS, Porto Alegre, RS, Brasil; heck@ufrgs.br.

\footnotetext{
* Technical contribution to the $69^{\text {th }} A B M$ International Annual Congress and to the ENEMET, July $21^{\text {st }}-25^{\text {th }}$, 2014, São Paulo, SP, Brazil.
} 


\section{INTRODUCTION}

The reduction in operating temperature of planar solid oxide fuel cells (SOFCs) to the $600-800^{\circ} \mathrm{C}$ temperature range has allowed the use of ferritic stainless steels as replacement for conventional lanthanum chromite ceramics for construction of interconnects in SOFC stacks [1]. Ferritic stainless steels offer many advantages over traditional ceramic interconnects, such as higher thermal and electronic conductivity, reasonable thermal expansion matching, relative ease of fabrication and decreased machining costs. Despite of these positive aspects, several issues potentially hamper their application, such as the formation of thermally grown chromium oxide on ferritic stainless steels, which results in an increase in ohmic resistance and can lead to the loss of cathode catalytic activity through $\mathrm{Cr}$ volatilization, which is known as cathode poisoning [2].

Oxidation of ferritic stainless steels has been extensively studied in literature [2-7]. It is found that the oxide growth depends on many factors, including alloy composition, oxygen partial pressure, temperature, and exposure time. As suggested by Dheeradhada et al. [2], the effect of alloy composition on the oxidation behavior can be very complex, in particular when dealing with minor alloying and impurity elements. Complex, stratified thermally grown oxide layers often evolve on ferritic stainless steels during SOFC cathode gas exposures, forming several different condensed phases (e.g. $\mathrm{Cr}_{2} \mathrm{O}_{3},\left(\mathrm{Cr}, \mathrm{Mn}_{3} \mathrm{O}_{4}, \mathrm{SiO}_{2}\right.$, and/or $\mathrm{Fe}_{2} \mathrm{O}_{3}$ ), amorphous oxides and/or solid solutions [8]. In this way, it is believed that thermodynamic modeling can contribute to the systematic understanding of oxidation behavior of ferritic stainless steels. In the present work, firstly we carried out a thermodynamic study for the oxidation of a Fe-20wt\% $\mathrm{Cr}$ alloy. Then, the study was performed for ferritic stainless steel 430 (composition, in wt\%: $\mathrm{Fe}=77.88, \mathrm{Cr}=20, \mathrm{Mn}=1.0, \mathrm{Si}=1.0$ and $\mathrm{C}=0.12$ ). The effects of alloying elements, such as $\mathrm{Mn}$ and $\mathrm{Si}$, on the phases that compose the stratified grown oxide are discussed. The results obtained with the help of FactSage software are compared with the experimental trends reported in the literature.

\section{MATERIAL AND METHODS}

Thermodynamic equilibrium calculations using the Gibbs energy minimization approach were carried out using the commercial software FactSage 6.3. The Equilib module determines through a minimization routine the different values of number of moles, molar fraction and partial pressure that minimize the objective function (Gibbs energy of the system), subject to the elemental mass balance constraints [9]. Table 1 shows the databases and species considered in the thermodynamic calculations. A detailed description of FactSage thermochemical software and databases can be seen in Refs. [10-12].

\footnotetext{
* Technical contribution to the $69^{\text {th }} A B M$ International Annual Congress and to the ENEMET, July $21^{\text {st }}-25^{\text {th }}$, 2014, São Paulo, SP, Brazil.
} 


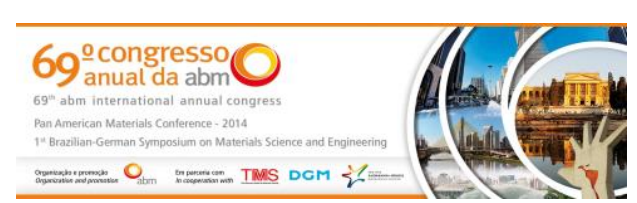

Table 1. Databases and species considered in equilibrium computations using FactSage.

\begin{tabular}{|c|c|}
\hline Phases & Databases \\
\hline Ideal gas $\left(\mathrm{O}_{2}\right)$ & SGPS \\
\hline Pure solid compounds $\left(\mathrm{SiO}_{2}\right)$ & SGPS \\
\hline \multirow{13}{*}{$\begin{array}{l}\text { Solid solutions describing the } \\
\text { metal, carbides and oxides }\end{array}$} & FSstel-FCC1 (FCC_A1) \\
\hline & FSstel-BCC1 (BCC_A2) \\
\hline & FSstel-CEME (CEMENTITE) \\
\hline & FSstel-M23C $\left(\mathrm{M}_{23} \mathrm{C}_{6}\right)$ \\
\hline & FSstel-SIGM (SIGMA) \\
\hline & $\begin{array}{l}\text { FToxid-SPINA } \\
\text { (ASpinel-cubic) }\end{array}$ \\
\hline & FSstel-MONO (Monoxide) \\
\hline & $\begin{array}{l}\text { FToxid-SPINB } \\
\text { (BSpinel-cubic) }\end{array}$ \\
\hline & FToxid-MeO_B (BMonoxide) \\
\hline & FToxid-CORU $\left(\mathrm{M}_{2} \mathrm{O}_{3}\right.$-CORUNDUM $)$ \\
\hline & FToxid-TSpi (Tetragonal Spinel) \\
\hline & FToxid-Bixb $\left(\mathrm{Mn}_{2} \mathrm{O}_{3}\right.$ - Bixbyite) \\
\hline & FToxid-MeO_A (AMonoxide) \\
\hline
\end{tabular}

\section{RESULTS AND DISCUSSION}

\subsection{Understanding the Oxidation Behavior of $\mathrm{Fe}-20 \mathrm{wt} \% \mathrm{Cr}$}

Figure 1 shows the calculated phase diagram for the ternary $\mathrm{Fe}-\mathrm{Cr}-\mathrm{O}$ system at $750^{\circ} \mathrm{C}$. One can see from the isothermal section that the Corundum phase $\left((\mathrm{Fe}, \mathrm{Cr})_{2} \mathrm{O}_{3}\right)$ forms a continuous solid solution between two stoichiometric compounds - $\mathrm{Fe}_{2} \mathrm{O}_{3}$ and $\mathrm{Cr}_{2} \mathrm{O}_{3}$. Similarly, the Spinel phase forms a continuous solid solution between the pure phases $\mathrm{Fe}_{3} \mathrm{O}_{4}$ and $\mathrm{FeCr}_{2} \mathrm{O}_{4}$. The Monoxide phase is essentially composed of $\mathrm{FeO}$, forming a solid solution with a very small amount of other oxides, such as $\mathrm{Fe}_{2} \mathrm{O}_{3}$ and $\mathrm{Cr}_{2} \mathrm{O}_{3}$. Thus, the stability region of Monoxide phase corresponds approximately to the stoichiometric composition of $\mathrm{FeO}$. Note that only the Corundum phase can be in equilibrium with the gas phase $\left(\mathrm{O}_{2}\right)$. Interestingly, for a Fe-rich alloy, in this case $\mathrm{Fe}-20 \mathrm{wt} \% \mathrm{Cr}$, the BCC phase (Fe-rich) coexists at the equilibrium with the stoichiometric $\mathrm{Cr}_{2} \mathrm{O}_{3}$. For a Cr-rich alloy, $\mathrm{BCC}$ phase is also in equilibrium directly with the $\mathrm{Cr}_{2} \mathrm{O}_{3}$ compound. In this way, from the phase diagram shown in Figure 1, one can conclude that at the metal/oxide interface $\mathrm{Cr}_{2} \mathrm{O}_{3}$ is anticipated to form in contact with the metallic alloy. Therefore, in order to thermodynamically model the stratified thermally grown oxide layers, it is worth presenting an analysis focused on the predominance diagram (or chemical potential diagram), as shown in Figure 2.

Figure 2 shows the calculated predominance diagram at $750^{\circ} \mathrm{C}$. At $\mathrm{pO}_{2}$ higher than $10^{-10}$ atm, Corundum is the most stable phase, and this phase can be majorly constituted by $\mathrm{Fe}_{2} \mathrm{O}_{3}$ or $\mathrm{Cr}_{2} \mathrm{O}_{3}$, depending on the $\mathrm{Cr}$ content of the alloy. At lower values of $\mathrm{pO}_{2}$, several oxides are present, such as Spinel, Corundum (stoichiometric $\mathrm{Cr}_{2} \mathrm{O}_{3}$ ), Monoxide (FeO). At very low value of $\mathrm{pO}_{2}$, the first oxide that is formed is stoichiometric $\mathrm{Cr}_{2} \mathrm{O}_{3}$, which is in direct contact with the metal alloy. In this way, for a Fe-20wt\%Cr alloy, exposed to the cathode atmosphere, the stratified oxide layer can be described as follows (see also Figure 3):

\footnotetext{
* Technical contribution to the $69^{\text {th }}$ ABM International Annual Congress and to the ENEMET, July $21^{\text {st }}-25^{\text {th }}$, 2014, São Paulo, SP, Brazil.
} 
- inner layer, very low $\mathrm{pO}_{2}\left(\sim 10^{-27} \mathrm{~atm}\right)$, corresponding to the point 2: metal is directly covered by stoichiometric $\mathrm{Cr}_{2} \mathrm{O}_{3}$;

- intermediate layers, which correspond to intermediate values of $\mathrm{pO}_{2}\left(10^{-22}\right.$ $10^{-11}$ atm, see the points $3,4,5$, and 6 ): over the protective $\mathrm{Cr}_{2} \mathrm{O}_{3}$ phase, stoichiometric phases $\mathrm{FeCr}_{2} \mathrm{O}_{4}$ and $\mathrm{FeO}$, as well as the solid solution Spinel $\left(\mathrm{Fe}_{3} \mathrm{O}_{4}+\mathrm{FeCr}_{2} \mathrm{O}_{4}\right.$, richer in $\left.\mathrm{Fe}_{3} \mathrm{O} 4\right)$ are formed, in this order.

- outer layer, corresponding to higher values of $\mathrm{pO}_{2}\left(>10^{-10} \mathrm{~atm}\right.$, see point 7): Corundum solid solution phase, $(\mathrm{Fe}, \mathrm{Cr})_{2} \mathrm{O}_{3}$, composed majorly by $\mathrm{Fe}_{2} \mathrm{O}_{3}$, is formed, and it is in direct contact with the gas phase.

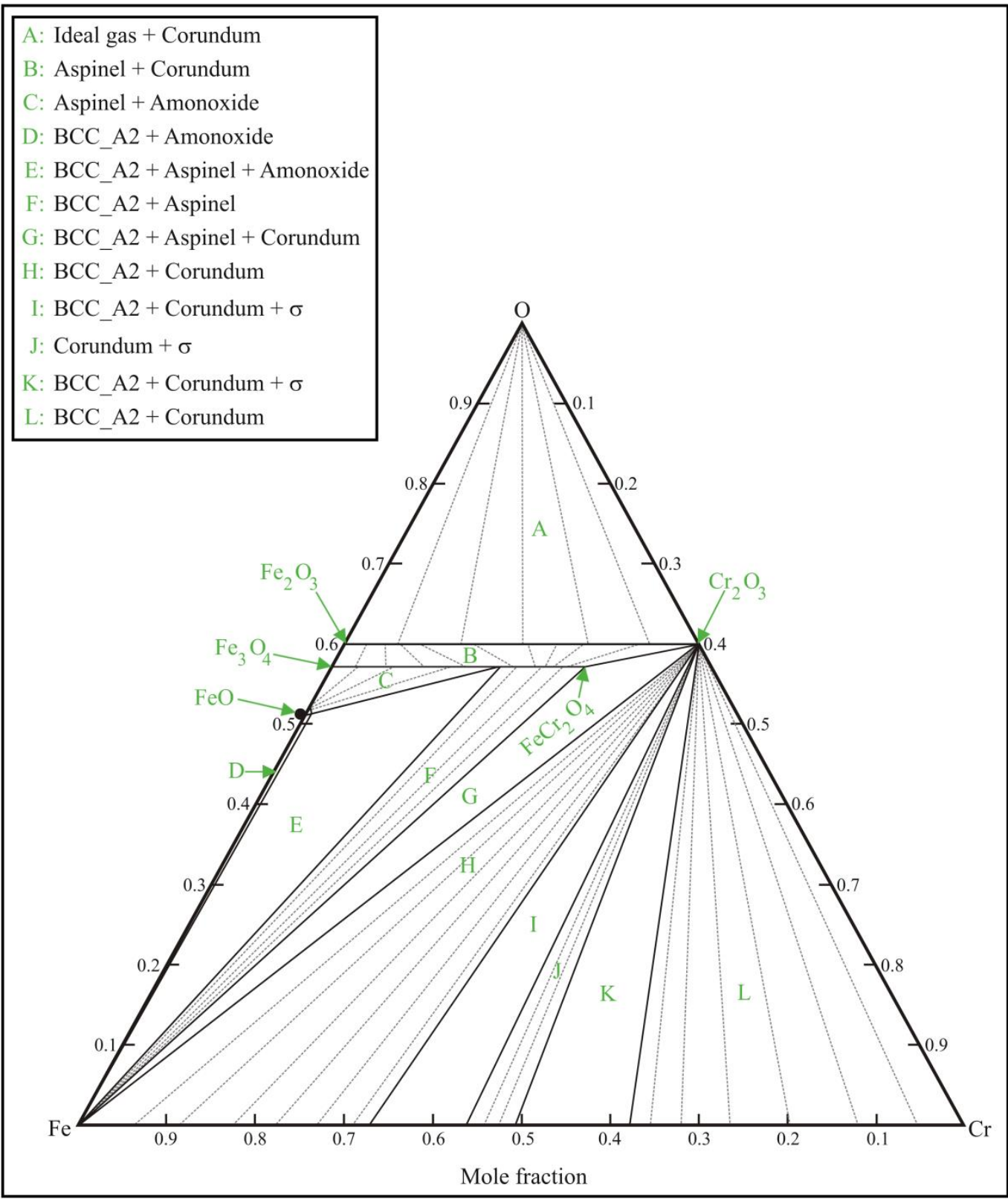

Figure 1. Fe-Cr-O phase diagram. Isothermal section at $750^{\circ} \mathrm{C}$.

* Technical contribution to the $69^{\text {th }}$ ABM International Annual Congress and to the ENEMET, July $21^{\text {st }}-25^{\text {th }}$, 2014, São Paulo, SP, Brazil. 


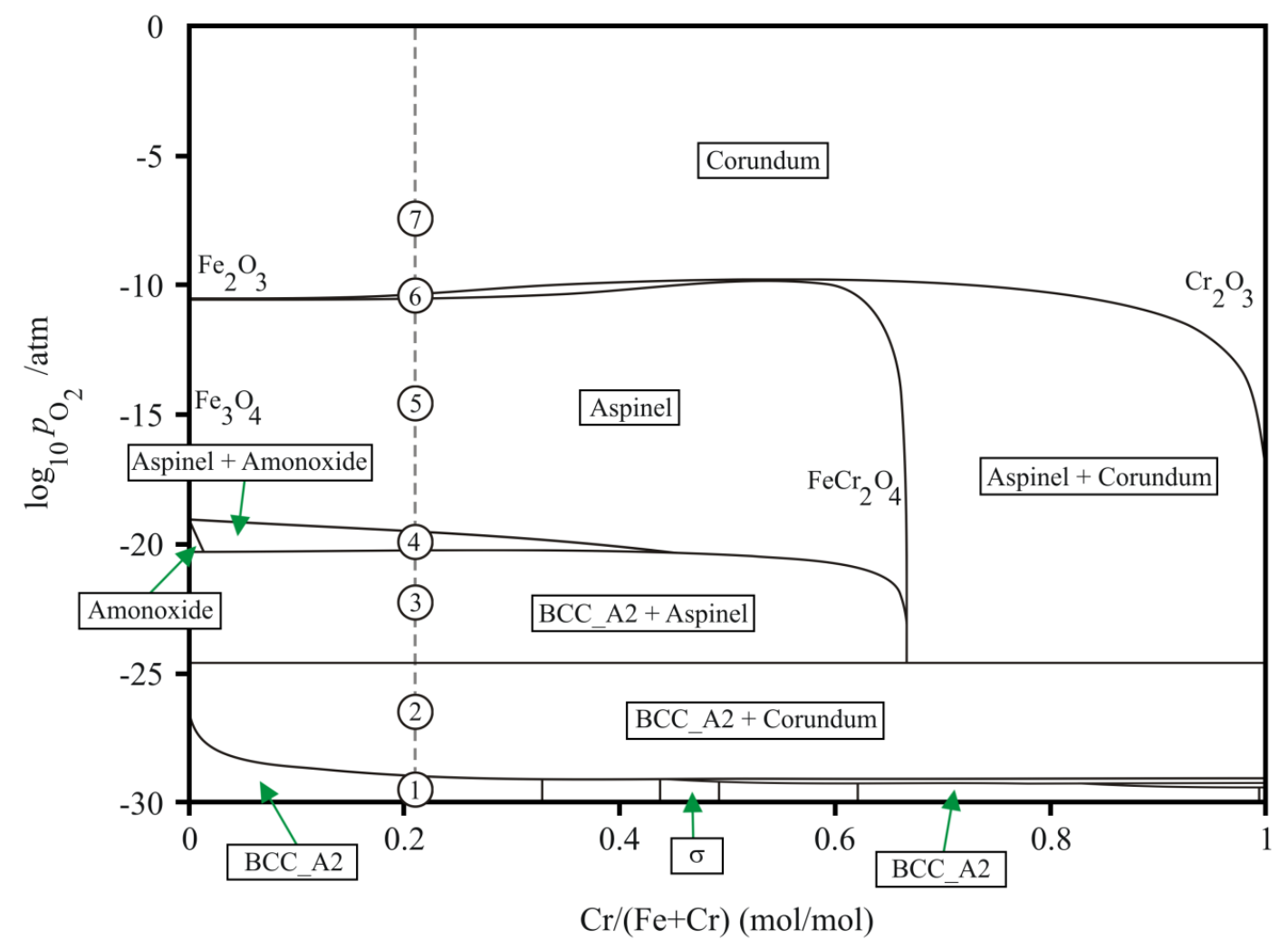

Figure 2. Predominance diagram of Fe-Cr-O at $750^{\circ} \mathrm{C}$. Dashed line refers to $\mathrm{Fe}-20 \mathrm{wt} \% \mathrm{Cr}$ alloy.

$$
\begin{array}{|c|c|}
\hline \mathrm{Fe}_{2} \mathrm{O}_{3} \\
\hline \mathrm{Fe}_{3} \mathrm{O}_{4} \\
\hline \mathrm{FeO} \\
\cline { 2 - 2 } \mathrm{FeCr}_{2} \mathrm{O}_{4} \\
\hline \mathrm{Cr}_{2} \mathrm{O}_{3} \\
\hline \mathrm{Fe}-20 \% \mathrm{Cr} \\
\hline
\end{array}
$$

Figure 3. Schematic stratified thermally grown oxide layers for $\mathrm{Fe}-20 \mathrm{wt} \% \mathrm{Cr}$ alloy.

Figure 4 shows, for the values of $\mathrm{pO}_{2}$ that correspond to the points 1-7 in Figure 2, the amount of each phase predicted in the predominance diagram for the $\mathrm{Fe}$ $20 \mathrm{wt} \% \mathrm{Cr}$ alloy. Figure 5 depicts the composition of each phase. From Figure 5(a), one can see that while the Corundum phase that is direct contact with the Fe-Cr alloy is composed only by the stoichiometric $\mathrm{Cr}_{2} \mathrm{O}_{3}$, the Corundum phase formed at the outer layer in contact with the gas phase is composed majorly by $\mathrm{Fe}_{2} \mathrm{O}_{3}$. Figure $5(\mathrm{~b})$ shows that the Spinel phase formed in the innermost layers is essentially formed by the $\mathrm{FeCr}_{2} \mathrm{O}_{4}$ compound. However, the Spinel phase becomes gradually richer in $\mathrm{Fe}_{3} \mathrm{O}_{4}$ towards to outer layers. From Figure 5(c), it is possible to observe that the Monoxide phase, which appears in the intermediate layers, is greatly composed of $\mathrm{FeO}$, with a very small amount of $\mathrm{Fe}_{2} \mathrm{O}_{3}$ and $\mathrm{Cr}_{2} \mathrm{O}_{3}$. By comparing with experimental observations, one can see that the same predicted phases are found in the oxidized stainless steels $[1,7]$.

* Technical contribution to the $69^{\text {th }} A B M$ International Annual Congress and to the ENEMET, July $21^{\text {st }}-25^{\text {th }}$, 2014, São Paulo, SP, Brazil. 

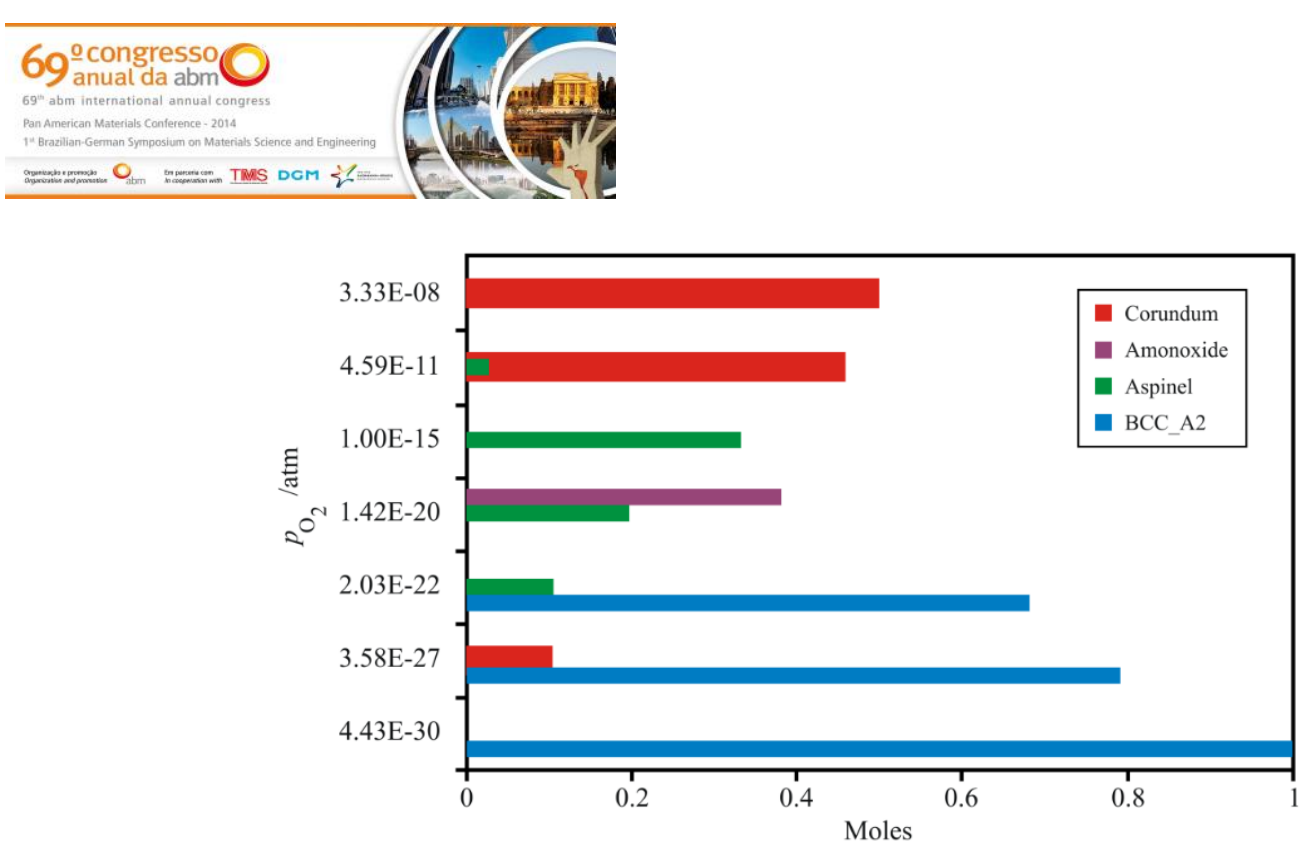

Figure 4. Moles of phases as a function of $\mathrm{pO}_{2} . T=750^{\circ} \mathrm{C}$. The values of $\mathrm{pO}_{2}$ correspond to the points 1-7 indicated in Figure 2.

(a)

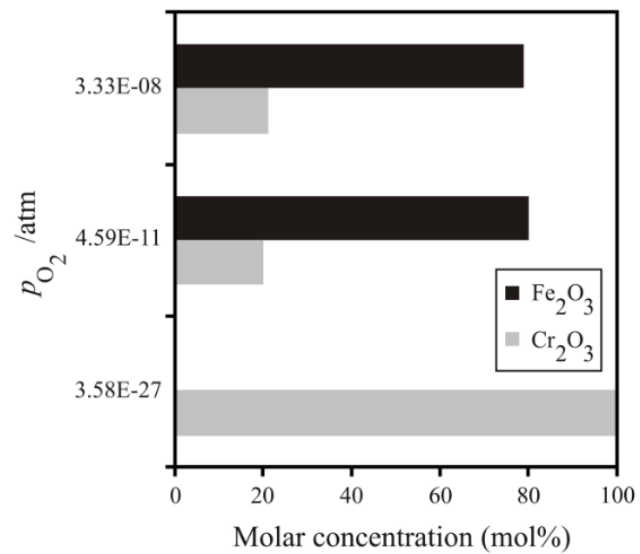

(b)

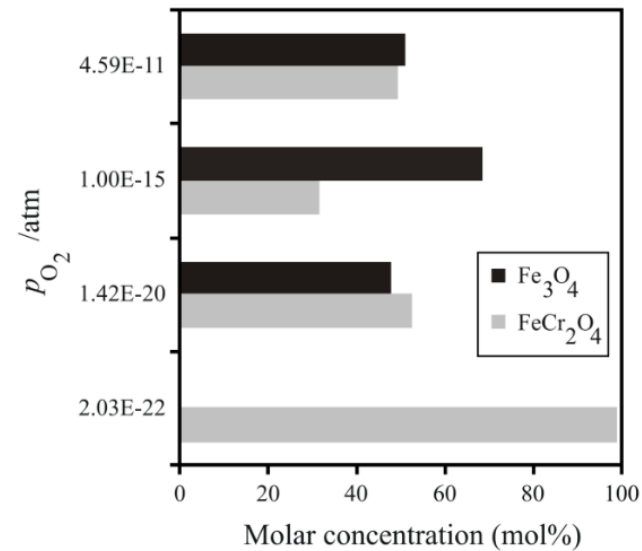

(c)

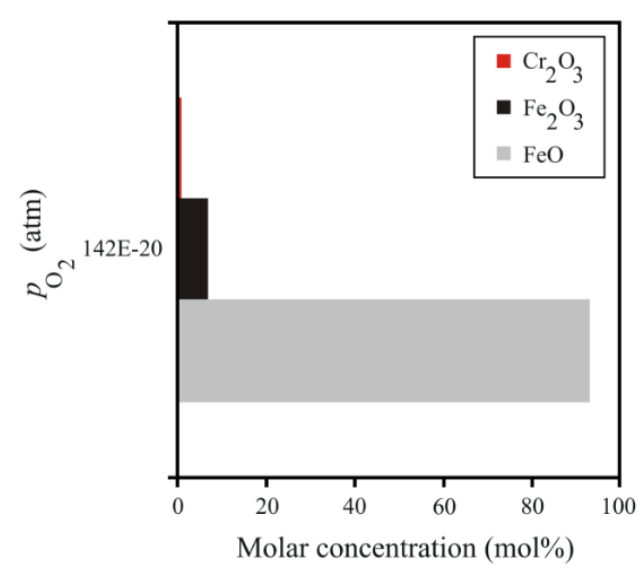

Figure 5. Composition of Corundum (a), Spinel (b) and Monoxide (c), in mol\%, as a function of $\mathrm{pO}_{2}$. $T=750^{\circ} \mathrm{C}$. The values of $\mathrm{pO}_{2}$ correspond to the points 1-7 indicated in Figure 2.

\subsection{Understanding the Oxidation Behavior of the Ferritic Stainless Steel 430}

In the present section, the complexity of the thermodynamic system is increased, since $\mathrm{Mn}, \mathrm{Si}$ and $\mathrm{C}$ elements are added. The study was performed for ferritic stainless steel 430 (composition, in wt\%: $\mathrm{Fe}=77.88, \mathrm{Cr}=20, \mathrm{Mn}=1.0, \mathrm{Si}=1.0$ and $\mathrm{C}=0.12$ ). Figure 6 shows the metallic and carbide phases as a function of $\mathrm{pO}_{2}$. One

* Technical contribution to the 69th $A B M$ International Annual Congress and to the ENEMET, July $21^{\text {st }}-25^{\text {th }}, 2014$, São Paulo, SP, Brazil. 


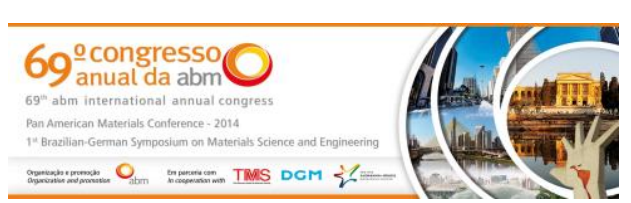

can see that carbides of the type $\mathrm{M}_{23} \mathrm{C}_{6}$ are, obviously, stable only at very low values of $\mathrm{pO}_{2}$. Under these conditions, the alloy composition is almost the same as its nominal composition. However, as $\mathrm{pO}_{2}$ increases, $\mathrm{Cr}$ is completely removed from the alloy, due to the oxidation process. At intermediate and higher values of $\mathrm{pO}_{2}$, the alloy in contact with the oxide is composed exclusively of $\mathrm{Fe}$ and $\mathrm{Mn}$, respectively. Due to the changes in the steel composition during oxidation, other phases can appear, such as cementite. Figure 7 (a) depicts the number of moles of each oxide phase as a function of $\mathrm{pO}_{2}$. Figure 7 (b), (c) and (d) shows the composition of the Corundum, Spinel and Monoxide phases, respectively, in mol\%. The first phase formed is $\mathrm{SiO}_{2}$, which appears at very low values of $\mathrm{pO}_{2}\left(<10^{-30} \mathrm{~atm}\right)$. This is related to the internal $\mathrm{SiO}_{2}$ experimentally observed between the metal/oxide interface [13]. Then, at relatively higher values of $\mathrm{pO}_{2}\left(10^{-29} \mathrm{~atm}\right)$, Spinel $\left(\mathrm{MnCr}_{2} \mathrm{O}_{4}\right)$ is in equilibrium with Corundum $\left(\mathrm{Cr}_{2} \mathrm{O}_{3}\right)$. Thus, $\mathrm{Mn}$ stabilizes the Spinel phase, since the formation of this phase occurs even at a very low value of $\mathrm{pO}_{2}$, in the innermost layers of the grown oxide. At intermediate values of $\mathrm{pO}_{2}\left(10^{-21}-10^{-20} \mathrm{~atm}\right)$, $\mathrm{FeO}$ can be formed. Note that at a higher value of $\mathrm{pO}_{2}\left(10^{-7} \mathrm{~atm}\right)$, corresponding to the outermost layers of the oxide, Spinel (composed mainly of $\mathrm{MnCr}_{2} \mathrm{O}_{4}+\mathrm{MnFe}_{2} \mathrm{O}_{4}$ ) is in equilibrium with the Corundum $\left(80 \% \mathrm{Fe}_{2} \mathrm{O}_{3}+20 \% \mathrm{Cr}_{2} \mathrm{O}_{3}\right)$. Interestingly, one can see that Spinel phase appears both in the innermost and outermost layers, in perfect agreement with the trends verified in Ref. [7,13].

(a)

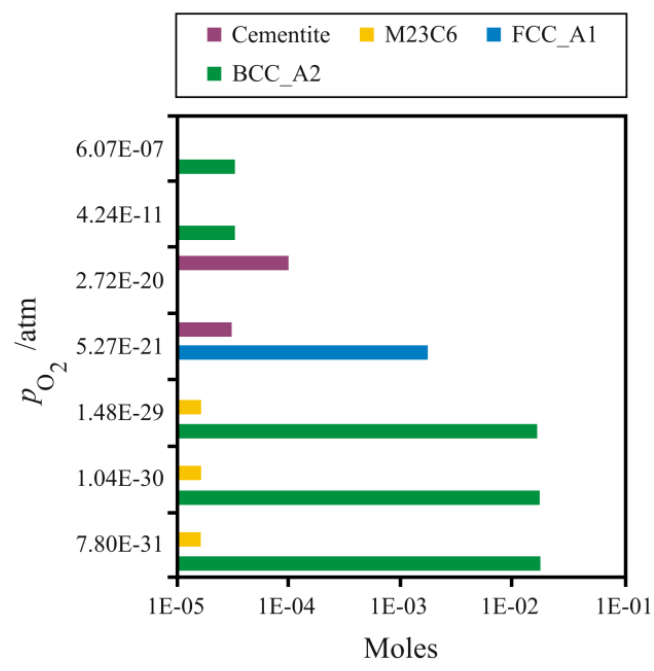

(b)

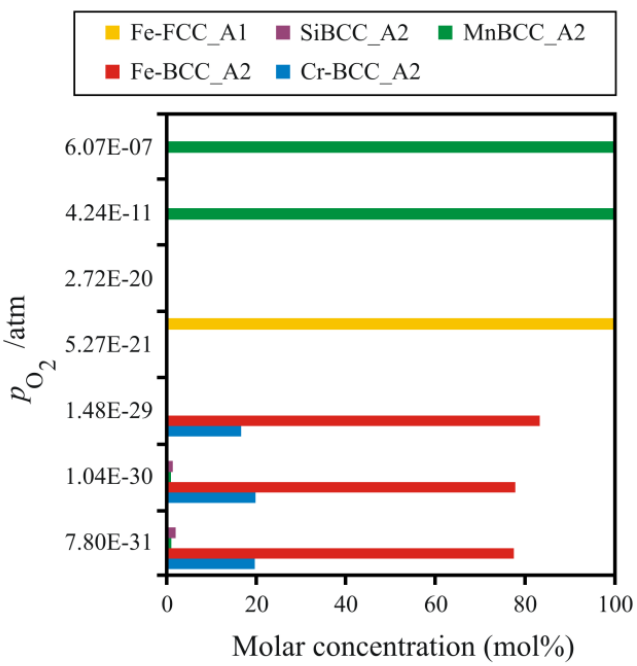

(c)

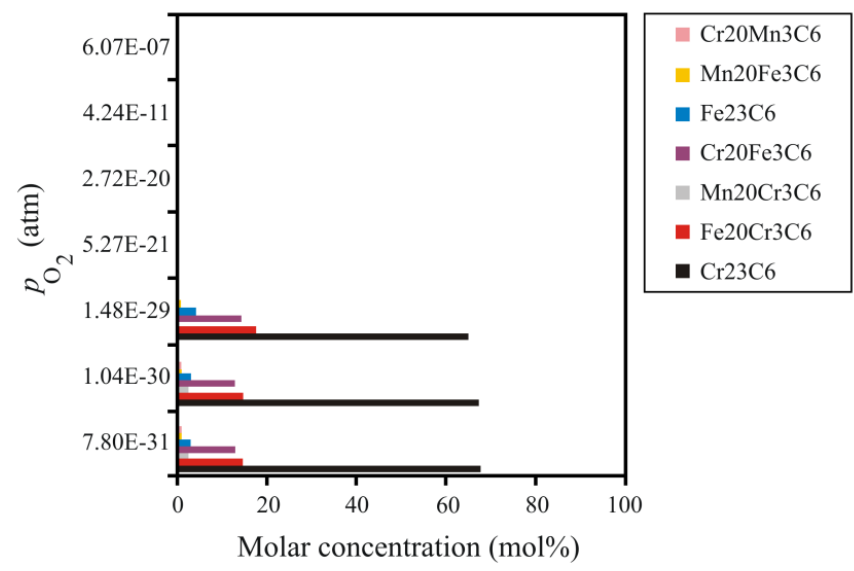

Figure 6. (a) Moles of metallic and carbide phases as a function of $\mathrm{pO}_{2}$. (b) Concentration of species, in $\mathrm{mol} \%$, in each phase as a function of $\mathrm{pO}_{2} . T=750^{\circ} \mathrm{C}$. Ferritic stainless steel 430.

\footnotetext{
* Technical contribution to the $69^{\text {th }}$ ABM International Annual Congress and to the ENEMET, July $21^{\text {st }}-25^{\text {th }}$, 2014, São Paulo, SP, Brazil.
} 
(a)

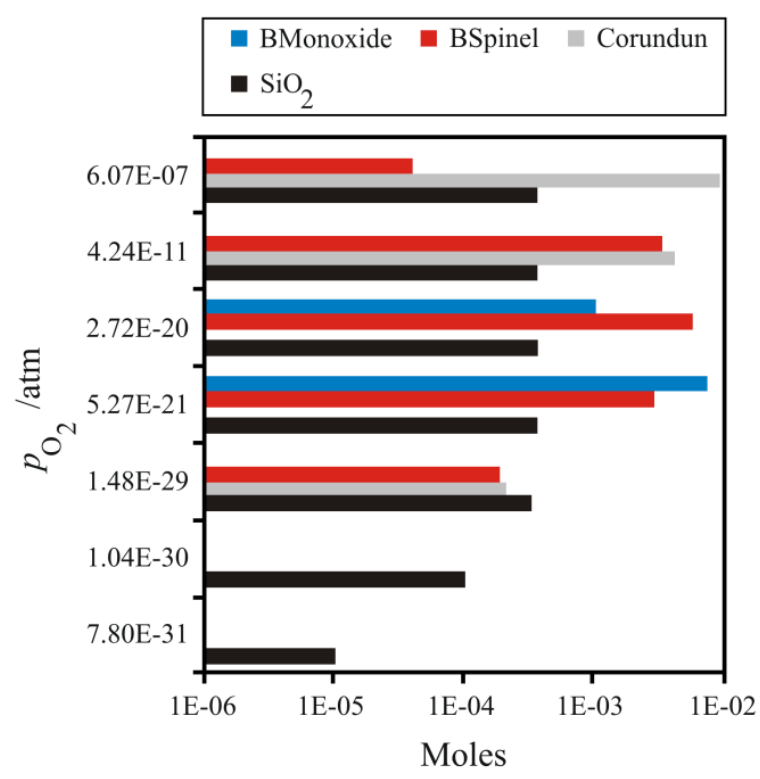

(c)

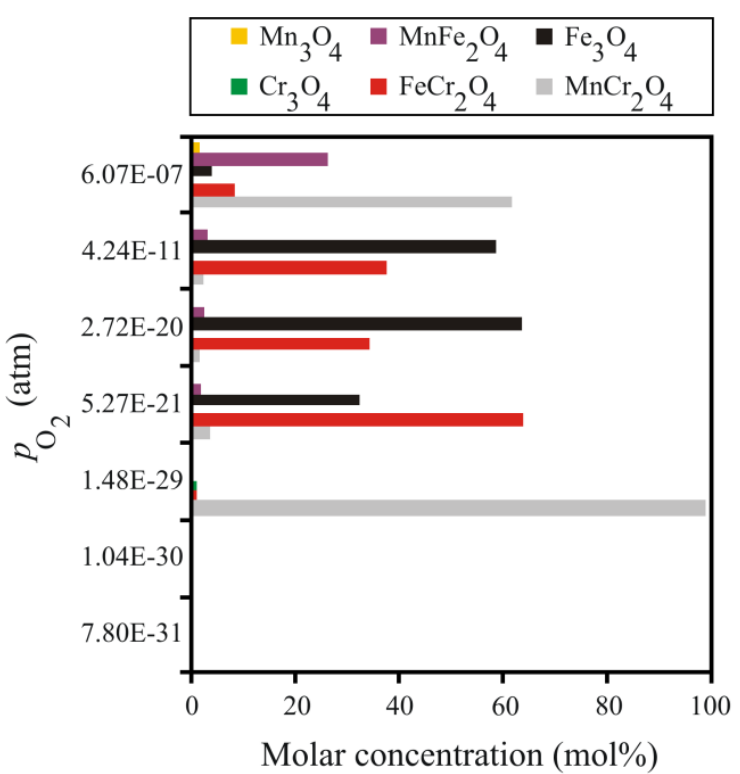

(b)

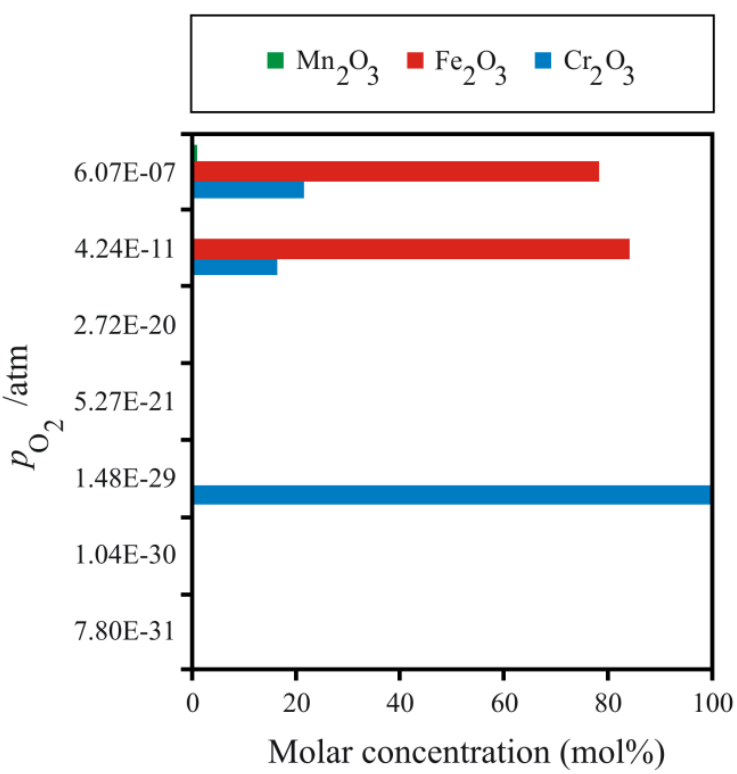

(d)

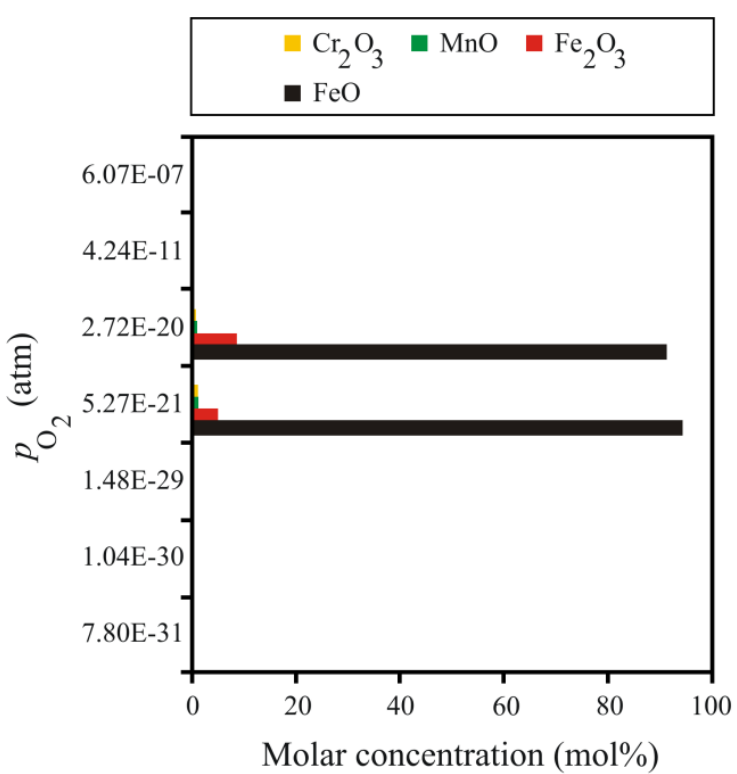

Figure 7. (a) Moles of oxide phases as a function of $\mathrm{pO}_{2}$. (b), (c) and (d) refer to the concentration of species, in mol\%, in Corundum, Spinel and Monoxide phases, respectively, as a function of $\mathrm{pO}_{2}$. $T=750^{\circ} \mathrm{C}$. Ferritic stainless steel 430.

\section{CONCLUSION}

The present research demonstrates the potential of thermodynamic modeling in the interpretation of the experimental trends observed during exposure of $\mathrm{Fe}-\mathrm{Cr}$ alloys to air (cathode atmosphere) at high temperatures. The understanding of the oxidation behavior can help in identifying the role of alloying elements in the stratified thermally grown oxide layer, and one can see the distribution of solid phases as well as their compositions as a function of partial pressure of oxygen. In the case of the ferritic stainless steel $430, \mathrm{SiO}_{2}$ appears between the metal/oxide interface, and Spinel is found both in the innermost and outer layers of the stratified thermally grown oxide. At lower value of $p_{2}$, Spinel phase is composed essentially by the $\mathrm{MnCr}_{2} \mathrm{O}_{4}$ compound, while at higher values $\mathrm{MnFe}_{2} \mathrm{O}_{4}$ tends to be stable together with

\footnotetext{
* Technical contribution to the $69^{\text {th }}$ ABM International Annual Congress and to the ENEMET, July $21^{\text {st }}-25^{\text {th }}$, 2014, São Paulo, SP, Brazil.
} 


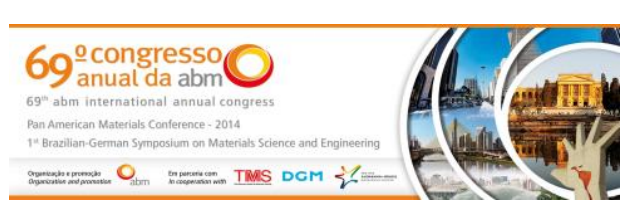

$\mathrm{MnCr}_{2} \mathrm{O}_{4}$. It is found that $\mathrm{Mn}$ greatly stabilizes the Spinel phase. The stabilization of Spinel phase, with the formation of a great amount of the $\mathrm{MnCr}_{2} \mathrm{O}_{4}$ phase, can have a significant impact on Cr volatilization and Area Specific Resistance (ASR).

\section{Acknowledgments}

The authors would like to thank FAPERGS (Fundação de Amparo à Pesquisa do Estado do Rio Grande do Sul) and CAPES (Coordenação de Aperfeiçoamento de Pessoal de Nível Superior) for their financial support (Postdoctoral fellowship - Edital 09/2012 - DOCFIX).

\section{REFERENCES}

1 Ebrahimifar H, Zandrahimi M. Solid State lonics. 2011; 183: 71-79.

2 Dheeradhada VS, Cao H, Alinger MJ. J. Power Sources. 2011; 196: 1975-1982.

3 Jian P., Jian L, Bing H, Xie G. J. Power Sources. 2006; 158: 354-360.

4 Yang Z, Xia G, Singh P, Stevenson JW. Solid State Ionics. 2005; 176: 1495-1503.

5 Huntz AM, Reckmann A, Haut C, Severac C, Herbst M, Resende FCT, Sabioni ACS. Mater. Sci. Eng. A. 2007; 447: 266-276.

6 Hansson AN, Somers MAJ. Mater. High Temp. 2005; 22: 223-229.

7 Rufner J, Gannon P, White P, Deibert M, Teintze S, Smith R, Chen H. Int. J. Hydrogen Energy. 2008; 33: 1392-1398.

8 Stevenson JW, Yang ZG, Xia GG, Maupin GD, Li XS, Singh P. SOFC interconnects and coatings. Presentation given at $7^{\text {th }}$ annual SECA workshop and peer review, Philadelfia, PA; 2006.

9 EquiSage.ppt. The Equilib module - Regular features. Index of/fact/factsage. www.crct.polymtl.ca/fact/factsage. (accessed October 2013).

10 Bale CW, Chartrand P, Decterov SA, Eriksson G, Hack K, Mahfoud RB, Melançon J, Pelton AD, Petersen S. Calphad. 2002; 26: 189-228.

11 FactSage 6.3 - Summary of Databases. www.crct.polymtl.ca/fact/documentation./FSData.htm. (accessed January 2014).

12 Bale CW, Bélisle E, Chartrand P, Decterov SA, Eriksson G, Hack K, Jung IH, Kang YB, Melançon J, Pelton AD, Robelin C, Petersen S. Calphad. 2009; 33: 295-311.

13 Seo Hs, Yun DW, Kim KY. Int. J. Hydrogen Energy. 2012; 37: 16151-16160.

* Technical contribution to the 69th $A B M$ International Annual Congress and to the ENEMET, July $21^{\text {st }}-25^{\text {th }}$, 2014, São Paulo, SP, Brazil. 